\title{
STX11 wt Allele
}

National Cancer Institute

\section{Source}

National Cancer Institute. STX11 wt Allele. NCI Thesaurus. Code C114620.

Human STX11 wild-type allele is located in the vicinity of $6 q 24.2$ and is approximately 41 $\mathrm{kb}$ in length. This allele, which encodes syntaxin-11 protein, is involved in the regulation of protein transport between late endosomes and the trans-Golgi network. Mutations in this gene are associated with familial hemophagocytic lymphohistiocytosis type 4 . 